\title{
Una interpretación bíblica feminista a partir de una aproximación a (Hch16,13-15,40) y (Hch 16,16-18) en diálogo con testimonios de mujeres cabeza de familia en Colombia*
}

Adriana Alejandra Hoyos Camacho**

\section{Resumen}

Una aproximación entre mujeres del Nuevo Testamento y de hoy, permite que la teología, a partir de una interpretación feminista, evidencie el protagonismo de la mujer en contextos de inequidad. Además, facilita descubrir la revelación de Dios, voluntad de Dios, en el ser humano mismo, en la iglesia primitiva y en la vida de la mujer latinoamericana. Al entretejer narrativas del pasado y del presente es posible tomar conciencia de las estructuras de dominación frente a la mujer. Igualmente, conlleva a elaborar visiones de democracia a partir de la correspondencia que existe entre el principio crítico feminista y el anuncio y seguimiento de Jesús.

El presente artículo de investigación, es parte del fruto del trabajo monográfico desarrollado por la autora, para lograr el título de Magister en Teología en la Pontificia Universidad Javeriana. Este texto pretende ser un aporte para la construcción de la equidad de género en nuestro país, y para la teología y hermenéutica feminista latinoamericana.

** Psicóloga de la Universidad Católica de Colombia 2003, Administradora de Empresas de la Escuela de Administración de Negocios EAN de Colombia 1995, Maestra en Teología de la Pontificia Universidad Javeriana de Bogotá 2008. Actualmente es profesora asistente del Departamento de Teología de la Universidad Javeriana de Bogotá. Miembro del grupo Academia inscrito en Colciencias. Contacto: aahoyos@hotmail.com. 


\title{
Palabras clave
}

Hermenéutica feminista, mujeres, relatos bíblicos, diálogo, equidad.

\section{A feminist biblical interpretation from an approximation to (Hch 16,13 to 15.40 ) and (Hch 16, 16-18) in dialogue with the testimonies of head of household women in Colombia}

\begin{abstract}
A rapprochement between women of the New Testament and women today, allows that theology, from a feminist interpretation, evinces the role of women in situations of inequity. Moreover, it facilitates to discover the revelation of God, the will of God, in man himself, in the early church, and in the life of Latin American women. By weaving narratives of the past and the present it is possible to be aware of the structures of domination over women. Also, it allows to develop visions of democracy from a correspondence between theocratic feminist principle, and the announcement of the following of Jesus.
\end{abstract}

Keywords

Feminist hermeneutics, women, bible stories, dialogue, equity. Introducción

Abordar reflexiva y transformadoramente la situación de inequidad que viven las mujeres en Colombia es una tarea en construcción, 
como lo evidencian algunas políticas y programas de gobierno, ciertos estudios realizados por universidades privadas y públicas, y las prácticas que realizan diversas instituciones y asociaciones que luchan por los derechos de las mujeres y propician condiciones hacia la igualdad de éstas al incorporar dentro de su quehacer la dimensión de género ${ }^{1}$.

No obstante, cuando se analizan los avances realizados al respecto, se constata un limitado compromiso y reflexión sobre el tema, en sectores de la sociedad como la familia, la escuela, la empresa privada, la academia, los distintos saberes y la Iglesia. De más, se percibe la necesidad de concretar desde estos ámbitos aportes significativos para la construcción de la equidad de género en nuestro país. Vale la pena subrayar, que el logro de una tarea de concienciación como esta, amerita de la participación constante de sectores que inciden permanentemente en la transformación de la sociedad como son la Iglesia y disciplinas humanistas como la teología.

La teología más que ser un discurso sobre Dios, que cuenta con una metodología y principios particulares, que se ubica en un contexto delimitado, con una lógica propia, y que opera desde una hermenéutica, tiene como objeto la experiencia de Dios revelada que se deja experimentar en la historia y que comunica su voluntad en

1 Entre estos: la actual política de gobierno orientada hacia la paz, la equidad y la igualdad de oportunidad para las mujeres. Algunas reflexiones, cifras y legislación sobre violencia intrafamiliar; informes estadísticos sobre la participación política de las mujeres en Colombia; pronunciamientos de la Corte Constitucional frente a los derechos de la mujer: investigaciones sobre el impacto del desplazamiento forzado sobre la mujer en Colombia, realizadas por la Universidad Nacional de Colombia; y algunos estudios sobre género realizados por diferentes ciencias sociales y por disciplinas como la teología, Cf. Dora Isabel Díaz, Situación de la mujer rural colombiana. Perspectiva de género. Cuadernos Tierra y Justicia 9 (Bogotá: ILSA, 2002). Fabiola Campillo, "El trabajo doméstico no remunerado en la economía," en Macroeconomía, Género y Estado (Bogotá: TM Editores, 1998). Argelia Londoño Vélez, Derecho a los Derechos. Atención integral a sobrevivientes de delitos sexuales (Bogotá: Consejería Presidencial para la Política Social y Fondo de Población de las Naciones Unidas, 2001). De autores institucionales: República de Colombia, Consejería presidencial para la equidad de la mujer. Informe de Gestión (Bogotá: 1999); Universidad Nacional de Colombia. CID. UNICEF, "¿Equidad de Género? ¿Equidad social? Una mirada desde la educación y el trabajo", Observatorio de Coyuntura Socioeconómica 14 (diciembre 2002); Instituto Nacional de Medicina Legal y Ciencias Forenses y Fondo de Prevención Vial, Forensis, datos para la vida (Bogotá: 2002). Profamilia, Encuesta nacional de demografía y salud ENDS (Bogotá: 2000). 
el ser humano y en su realidad ${ }^{2}$. Y, ya que para la teología no existe hombre y mujer, cultura o sistema socio-histórico en donde no estén dados signos claros y claves del acontecer de Dios ${ }^{3}$, le es posible intentar descubrir la presencia guía de Dios en los problemas de las comunidades en contextos específicos ${ }^{4}$.

Intentar construir un diálogo entre el quehacer teológico y fenómenos sociales particulares como la situación de inequidad que viven las mujeres cabeza de familia ${ }^{5}$ en América Latina, y particularmente en Colombia, puede permitir re-significar la situación y papel de cientos de mujeres en tiempos de opresión y también de liberación. En este sentido, el anuncio sobre la liberación compartido por Jesucristo es la matriz que da sentido a la existencia humana en situaciones reales de vulnerabilidad. Tal proclamación: más libertad, más justicia, más participación y más igualdad, ilumina con luz sorprendente la difícil realidad que viven las mujeres en contextos concretos ${ }^{6}$. Asimismo, facilita conocer que el Éxodo de Jesús, a través de la muerte, hacia la resurrección es donde la justicia de Dios queda totalmente revelada como "Poder de vida" en favor de los seres humanos.

En continuidad con lo anterior, al volver sobre narraciones bíblicas de mujeres como es el caso de Lidia de Tiatira ${ }^{7}$ (Hch 16,13-

2 Gustavo Baena, Apuntes personales en el marco de la Jornada de Reflexión sobre Investigación Facultad de Teología de la Pontificia Universidad Javeriana Bogotá (9 de enero de 2008): 1.

3 Ibíd., 2.

4 Rodolfo de Roux, Apuntes personales en el marco de la Jornada de Reflexión sobre Investigación. Facultad de Teología de la Pontificia Universidad Javeriana de Bogotá (9 de enero de 2008) : 4.

$5 \quad$ La Ley 82 de 1993 señala; "mujer cabeza de familia, es quien siendo soltera o casada, tenga bajo su cargo, económica o socialmente, en forma permanente, hijos menores propios u otras personas incapaces o incapacitadas para trabajar, ya sea por ausencia permanente o incapacidad física, sensorial, psíquica o moral del cónyuge o compañero permanente o deficiencia sustancial de ayuda de los demás miembros del núcleo familiar". Se subraya que a pesar de tanta regulación, la realidad para la mujer colombiana es difícil y excluyente en todos los campos: laboral, político, académico, entre otros. La mayoría de hogares pobres del país tienen como cabeza de familia a una mujer.

6 Benjamín Forcano y Leonardo Boff, Liberación de Jesucristo por el camino de la opresión (Madrid: Nueva Utopia, 1997), 28.

$7 \quad$ Lidia acogió en su casa a misioneros cristianos, ofreciéndoles abrigo y protección dentro de una situación política de persecución (Hch 16,13ss). Lidia es una mujer de Tiatira que vivía en Filipos y que se dedicaba a la venta y producción de tintes. Véase estudio realizado por Ivoni Richter, "Reconstruir historias de Mujeres: consideraciones acerca del trabajo y status de Lidia en Hechos 16", Revista de Interpretación Bíblica Latinoamericana 4 (1989): 47-59. 
15,40) y el relato de la esclava profetisa de Filipos (Hch 16,16-18) ${ }^{8}$ que presenta Lucas, y al ponerlos en diálogo con historias de vida de mujeres cabeza de familia en Colombia ${ }^{9}$, el texto sagrado y la misma existencia de la mujer de hoy se actualizan y muestran el significado de la voluntad de Dios. Igualmente, permiten a la teología, mediante una interpretación bíblica feminista, evidenciar el importante papel de las mujeres en contextos marcados por la desigualdad.

En relación a lo expresado, el problema de la investigación, sobre el cual se construyó el presente artículo, se enunció de la siguiente forma: ¿̇De qué manera una aproximación al relato de la esclava con dones mánticos (Hch 16,16-18), en complemento con el relato de Lidia de Tiatira (Hch 16,13-15,40), en diálogo con historias de vida de mujeres cabeza de familia, puede constituir un horizonte de la revelación de Dios como posibilidad de construcción de la equidad de género en nuestro país?

En cuanto al objetivo de la investigación se propuso realizar una lectura teológica desde una perspectiva crítico feminista sobre los relatos anteriormente mencionados, como también en las experiencias de mujeres cabeza de hogar con el fin de descubrir el acontecer de Dios, en y a través, de la vida de ellas. El logro de lo anterior implicó: recuperar la memoria de Lidia y de la esclava profetisa de Filipos, propiciar un diálogo entre historias de mujeres cabeza de familia y relatos de mujeres de la primitiva comunidad cristiana y aplicar una hermenéutica feminista, a partir del modelo crítico de interpretación feminista de lo divino ${ }^{10}$ a los relatos bíblicos antes mencionados.

8 Esclava cuyo nombre no se conoce y que presenta Lucas en Hechos de los Apóstoles. Cuenta el relato que esta mujer posee el don de la profecía y que es un instrumento de lucro para sus dueños, debido a su trabajo religioso.

9 Mujeres colombianas cuya jefatura femenina se originó como consecuencia de violencia intrafamiliar y abandono, madre solterismo, viudez, desplazamiento forzado y fenómenos de migración.

10 Cf. Elisabeth Schüssler, En memoria de ella. Una reconstrucción teológico-feminista de los orígenes del cristianismo (Bilbao: Desclée, 1989). De la misma autora, Los caminos de la Sabiduría (Santander: Sal Terrae, 2004) y Pero ella dijo (Madrid: Ed. Trotta, 1996). 


\section{Metodología}

\subsection{Enfoque metodológico de la investigación}

Para el desarrollo de la investigación se utilizó la metodología teológica feminista latinoamericana ${ }^{11}$, lo cual implicó realizar tres tareas: una deconstrucción de las categorías androcéntricas con las cuales se analiza la realidad, una relectura de los manuscritos base de la $\mathrm{fe}^{12}$ desde la perspectiva feminista de género con categorías inclusivas, y una recuperación de la memoria histórica de las mujeres, a partir de la deconstrucción y reconstrucción con el fin de recuperar la experiencia y las angustias de las mujeres de ayer y de hoy.

Es de notar que el tratamiento de la metodología propuesta requirió dos fases para su desarrollo. Primero, una reconstrucción de los relatos que refieren a Lidia de Tiatira y a la esclava con dones mánticos que presenta Lucas en Hechos de los Apóstoles ${ }^{13}$, como también la construcción de una historia de vida representativa de la mujer cabeza de familia en Colombia ${ }^{14}$. Con el fin de reconstruir algunos aspectos de la historia de Lidia y de la esclava profetisa de Filipos fue necesario realizar una exploración documental socio-

11 Para Shüssler esta metodología vuelve sobre las experiencias de las mujeres. También es una metodología crítica respecto a la sociedad patriarcal. Gran parte del sufrimiento de la mujer se causa desde una visión androcéntrica. Por demás nace como reflexión de los fundamentos de la teología de la liberación. Usa la metodología del ver-juzgar-actuar; se ubica en la realidad de la mujer, la interpreta desde la palabra de Dios y delibera respecto a las acciones que pueden transformar dicha realidad

12 Relatos bíblicos: (Hch 16,13-15,40) y (Hch 16,16-18). Cf. Luis Alonso Schökel, La Biblia de Nuestro Pueblo (Bilbao: Ediciones Mensajero, S.A.U, 2006), 23-99.

13 Para lo cual fueron decisivos los estudios realizados por la biblista Ivoni Richter. Cf. "Reconstruir historias de Mujeres: consideraciones acerca del trabajo y status de Lidia en Hechos16", op. cit.; "Una esclava profetisa y misioneros cristianos íExperiencias de Liberación? Consideraciones sobre Hch 16,16-18", Revista de Interpretación Bíblica Latinoamericana 12 (1992): 117-133; "Recordar transmitir, actuar. Mujeres en los comienzos del cristianismo", Revista de Interpretación Bíblica Latinoamericana 22 (1996): 43-57.

14 La historia de Guadalupe es una construcción narrativa que concentra las vivencias de cinco mujeres cabeza de familia colombianas. Articular, en una sola, cinco historias es fruto de un proceso de triangulación de información, categorización y caracterización desde algunas categorías propias del análisis reconstructivo feminista. Este proceso puede consultarse en la monografía original. 
histórica ${ }^{15}$, ya que ésta permite obtener una serie de conocimientos sobre el tema que se desea estudiar.

Para la construcción de la historia de vida representativa de la mujer con jefatura femenina en Colombia se utilizó el método de historias de vida ${ }^{16}$. Este método tuvo la bondad de invitar a las mujeres jefes de hogar a analizar su historia familiar y social, de modo que pudieran comprender su situación actual y los diversos factores que han podido producirla.

La Metodología de historias de vida ofrece un marco interpretativo a través del cual el sentido de la experiencia humana se revela en relatos personales en un modo que da prioridad a las explicaciones individuales de las acciones más que a los métodos que filtran y ordenan las respuestas en categorías conceptuales predeterminadas... la serie de entrevistas, que da lugar a una historia de vida, tiene por objeto los modos y maneras con los que un individuo particular construye y da sentido a su vida en un momento dado; además puede apoyarse en otras fuentes de información documental ${ }^{17}$.

A la metodología teológica feminista latinoamericana se le sumó una hermenéutica feminista o interpretación crítica feminista, centrada en los aportes de Elisabeth Shüssler ${ }^{18}$ por comprender la espi-

15 Se ha ahondado en la misión de los discípulos, los movimientos de la primera generación, la expansión del cristianismo y la mujer en el cristianismo primitivo: en el movimiento de Jesús, en el libro de Hechos de los Apóstoles, en la tradición paulina, en el movimiento misionero cristiano, en las cartas auténticas de Pablo y en la tradición pospaulina. Cf. Rafael Aguirre, "La primera evangelización", en Kerigma, Discipulado y Misión: perspectivas actuales (Bogotá: CELAM, 2006): 95-141. Pablo Richard, "Los diversos orígenes del cristianismo: una visión en conjunto (30-70 d.c.)", Revista de Interpretación Bíblica Latinoamericana 22 (1996): 43-57. Ivoni Richter, "Recordar, transmitir, actuar. Mujeres en los comienzos del cristianismo", op. cit.; de la misma autora: "Sexualidad en tiempos escatológicos: una aproximación a la problemática del matrimonio y del celibato en los dos primeros siglos cristianos", Revista de Interpretación Bíblica Latinoamericana 29 (1998): 106-119; Ximena Vizcaíno, La mujer en la Iglesia: del silencio a la palabra, del olvido a la memoria, de la pasividad a la militancia. Colección Apuntes de Teología (Bogotá: PUJ, 2005); Mercedes Navarro, "Los apóstoles y sus hechos: mujeres en los hechos de los apóstoles", en En clave de mujer: relectura de Lucas (Bilbao: Desclee de Brouwer, 1998).

16 Cf. Alfonso Torres, Aprender a investigar en comunidad I (Bogotá: Unisur, 1996). Del mismo autor: Enfoques cualitativos y participativos en investigación social: aprender en comunidad II (Bogotá: Unad, 1997) y Estrategias y técnicas de investigación cualitativa (Bogotá: Unisur, 1996). También, F. Godard y G. Cabanes, Uso de las historias de vida en ciencia sociales (Bogotá: Universidad Externado, 1996).

17 Alfonso Torres, Aprender a investigar en comunidad I, op. Cit., 277.

18 Su teología se configura desde la teología de la liberación; critica el status quo y se elabora a partir de experiencias de opresión. Schüssler es una de las teólogas feminista que más ha ahondado en la hermenéutica feminista. 
ritualidad bíblica de la sabiduría/Sabiduría ${ }^{19}$, mediante la lectura y el entendimiento de la Biblia en clave de justicia y de transformación. Este horizonte de interpretación posibilitó estudiar la manera como pueden contextualizarse tales interpretaciones en la vida de mujeres insertas en estructuras de dominación, como es el caso de Lidia de Tiatira y la esclava profetisa dentro de su contexto. El enfoque interpretativo, anteriormente señalado, propone un punto de vista retórico-emancipador ${ }^{20}$ en función de que la Biblia ayude a tomar conciencia de la estructura de dominación y facilite elaborar visiones de democracia a partir de lo que transmiten los textos.

Los movimientos hermenéuticos ${ }^{21}$ que se utilizaron para la concreción de la hermenéutica crítico feminista, comprometida con la liberación, fueron en su orden de atención: la hermenéutica de la experiencia, la hermenéutica de la dominación y la ubicación social, la hermenéutica de la sospecha, la hermenéutica de la evaluación crítica, la hermenéutica de la imaginación creativa, la hermenéutica de la remembranza y la hermenéutica de la acción transformadora para el cambio ${ }^{22}$.

Estos movimientos hermenéuticos interactúan simultáneamente en el proceso de extraer sentido a un determinado texto bíblico como (Hch 16,16-18) en complemento con (Hch 16,13-15,40) o cualquier otro relato en contextos de globalización, exclusión y desigualdad.

\subsection{Proceso de recolección, análisis e interpretación de la información}

Con base en la metodología de investigación propuesta se realizó el proceso de recolección de información. Este proceso implicó tener en cuenta las categorías del análisis reconstructivo feminista

19 Sabiduría como carácter y mentalidad, y Sabiduría como representación bíblica feminista de lo divino.

20 Los textos tienen el objetivo de persuadir y argumentar.

21 Pasos de danza desarrollados por los estudios bíblicos feministas. Se resaltan los aportes realizados por Shüssler y Russel.

22 Pasos que serán explicados posteriormente. Cf. Elisabeth Schüssler, Los caminos de la Sabiduría, op. cit. 
y del análisis para una investigación en perspectiva de género, la población y muestra, los instrumentos de recolección de datos y la forma como se describe y explica la información.

Con el fin de realizar un análisis sobre los relatos que presenta Lucas en Hechos de los Apóstoles $(16,13-15,40)$ y $(16,16-18)$, y las historias de vida de cinco mujeres cabeza de familia en Colombia, se tuvieron en cuenta las siguientes categorías: mujer, opresión de las mujeres, género, androcentrismo, patriarcado, kyriarcado, kyriocentrismo, androginia, ginocentrismo y ekklesia de mujer.

La población se vio representada por dos mujeres de la primitiva comunidad cristiana y cinco mujeres madres cabeza de familia. Respecto a la muestra seleccionada, se contó con los relatos que refieren a Lidia de Tiatira y la esclava con dones mánticos. Igualmente, con las historias de vida de cinco madres cabeza de familia ${ }^{23}$.

\subsection{Instrumentos para la recolección de la información}

Una vez identificada la población y la muestra, se procedió al diseño de instrumentos que permitieron la recolección de la información. Los instrumentos se diseñaron con base en las categorías de análisis propuestas anteriormente señaladas.

Con el fin de reconstruir algunos aspectos de la vida de Lidia y de la esclava profetisa de Filipos se realizó una revisión documental sociohistórica mediante el uso de concordancias bíblicas ${ }^{24}$ y material bibliográfico específico. La información básica de los textos o material bibliográfico se recogió a través de reseñas.

23 Por razones de confidencialidad los apellidos de estas personas no serán divulgados, ni referenciados en el presente artículo. No obstante, debe tenerse en cuenta que las experiencias de vida de estas mujeres son reales y se utilizaron solo con fines académicos.

24 Se rastrearon las citas bíblicas que mostraban información sobre la identidad de Lidia de Tiatira y sobre la esclava profetisa (esclava de los dones mánticos). Las únicas concordancias que se encuentran al respecto son: (Hch 16,14), (Hch 16,40) y (Hch 16,16). Se consultó en: Biblia-IntraText. Disponible en: www.vatican.va/archive/ESLO506/_PWM.HTM. 20/02/2007, 1-2. Asimismo, se consultó Concordancia de las Sagradas Escrituras. Revisión de 1960 de la versión Reina Valera. Compilada por C.B. Denyer (Nashville: Editorial Caribe, 1978). 
En cuanto a la elaboración de la historia de vida representativa de la mujer cabeza de familia en Colombia se utilizó la técnica de entrevista en profundidad normal, grabaciones magnetofónicas, exploración a escenarios, charlas con familiares y/o amigos, fotografía y vídeos que muestran episodios o etapas de la vida de estas mujeres.

\subsection{Procesamiento de la información}

La presentación y organización de la información permitió realizar la lectura de los datos, teniendo en cuenta los objetivos de la investigación y las construcciones teóricas. Se sistematizaron los datos de la realidad obtenidos bajo cada categoría.

Respecto a los relatos de mujeres de la primitiva comunidad cristiana, se procedió de la siguiente forma: selección de sujetos, obtención de datos a través de revisión de material bibliográfico, registro de información a través de reseñas o resúmenes analíticos y reconstrucción sobre la vida de la esclava profetisa en complemento con la historia de Lidia de Tiatira.

En cuanto a la historia de vida de la mujer cabeza de familia en Colombia, se procedió de la siguiente forma: selección de sujetos, obtención de datos a través de entrevistas (diseño de la entrevista, aplicación de la entrevista a cada una de las mujeres cabeza de familia, revisión de cada entrevista y transcripción de cada entrevista), registro de datos, trascripción de las grabaciones ordenándolas o ensamblándolas en un relato continuo -narración- a partir de la construcción de historias de vida ${ }^{25}$.

\subsection{Análisis e interpretación de la información}

A partir de la reconstrucción histórica se aplicó la hermenéutica crítica feminista de la liberación ${ }^{26}$, suscrita dentro del paradigma retórico- 
emancipador ${ }^{27}$, teniendo en cuenta los siguientes aspectos: un análisis del contexto cultural de la época en que Hechos de los Apóstoles fue escrito y su función como texto y una aplicación de la hermenéutica crítica feminista en sus siete momentos o movimientos de danza.

A partir de la construcción de una historia de vida representativa de la mujer cabeza de familia en Colombia se realizó un reconocimiento de los patrones estructurales y mecanismos de deshumanización en la vida de estas mujeres a partir de las categorías de análisis propuestas y una reflexión teológico-social a partir del diálogo ${ }^{28}$ entre dos mujeres: la esclava profetisa de Filipos y Guadalupe, una madre cabeza de familia hoy ${ }^{29}$.

\section{Resultados de la investigación}

Puesto que la metodología feminista latinoamericana implica unas labores específicas y opera desde una hermenéutica específica, en el siguiente apartado se da respuesta a los objetivos planteados en la investigación.

\subsection{Recuperación de la memoria de dos mujeres}

A continuación se presenta una reconstrucción de algunos aspectos de la vida de Lidia y de la esclava profetisa. Estos relatos se

27 Según Shüssler son cuatro los paradigmas de los estudios bíblicos: "el paradigma hermenéutico cultural, el científico-positivista, el revelatorio doctrinal y el retórico-emancipador. Este último busca comprender los textos y las tradiciones bíblicas. Al igual, ofrece un espacio en el que es posible transformar tanto la auto comprensión, auto percepción y auto alienación de las mujeres como los marcos epistemológicos masculino-mayoritarios, las prácticas apolíticas e individualistas y las relaciones socio-políticas de colonización cultural propias de occidente. A diferencia de los paradigmas masculino-mayoritarios de interpretación el paradigma emancipador practica la interpretación bíblica en aras de la concienciación. De ahí que no tenga problema en especificar las lentes analíticas -los marcos teóricos- que emplea en el proceso de lectura. La identidad bíblico-religiosa moldeada por la escritura ha de ser de construida y reconstruida, en las lecturas siempre nuevas, desde la perspectiva de una praxis global de liberación de todas las mujeres. También la identidad cultural configurada por los discursos bíblicos debe ser cuestionada y transformada críticamente". Cf. Elisabeth Schüssler, Los caminos de la Sabiduría, op. cit.

28 Se considera como una aproximación narrativa.

29 No se trata de extrapolar historias del Nuevo Testamento e insertarlas en el hoy, puesto que el método utilizado realiza una debida contextualización, análisis e interpretación, con miras a vislumbrar la presencia reveladora de Dios en contextos de iniquidad y explotación. 
leyeron ${ }^{30}$ de manera complementaria, en virtud de que los horizontes de liberación y realización del acontecer de Dios, de una y otra, se encuentran relacionados ${ }^{31}$.

\section{La esclava profetisa y Lidia de Tiatira}

Para recuperar la historia de estas dos mujeres fue necesario tener presente que la misión de los paganos nació en el contexto de la misión de Israel. Asimismo, que los misioneros iban a las sinagogas judías de la diáspora, frecuentadas por paganos "temerosos de Dios", que no se habían convertido al judaísmo, pero que congeniaban con el monoteísmo y la moral judía ${ }^{32}$.

Esta apertura a los gentiles que se dio en la diáspora, fuera de Palestina, iba más allá de la tarea de Jesús, pero desarrollaba virtualidades de su mensaje. Jesús se acercaba a pecadores y publicanos, a los impuros de Israel. Los paganos, que tenían un papel mediato en la predicación de Jesús sobre el Reino de Dios, van a ser destinatarios inmediatos de la acción de sus discípulos ${ }^{33}$.

Ahora bien, para introducir la escena:

Nos embarcamos en Tróade, llegamos rápidamente a Samocracia y al día siguiente a Neápolis; de allí a Filipos, la primera ciudad de la provincia de Macedonia, colonia romana. Nos quedamos unos días en aquella ciudad (Hch 16,11-12).

Según la anterior narración, Pablo llega a la ciudad de Filipos, jurisdicción de Macedonia. Esta ciudad era como una pequeña Roma y sus habitantes gozaban de los mismos derechos que si vivieran en la gran urbe.

El sábado, Pablo y Silas salen de la ciudad, a la orilla del río, donde había un espacio para orar:

30 Cf. Concilium, Las escrituras sagradas de las mujeres 276 (junio 1998); Daniel Marguerat e Yvan Bourquin, Cómo leer los relatos bíblicos (Santander: Editorial Sal Terrae, 2000).

31 Para lo cual fue decisivo el trabajo realizado por la Biblista, Ivoni Richter. Cf. "Recordar, transmitir actuar. Mujeres en los comienzos del cristianismo", op. cit.

32 Rafael Aguirre, La primera evangelización, op. cit., 8.

33 Ídem. 
Nos sentamos y nos pusimos a conversar con unas mujeres. Nos escuchaba una mujer llamada Lidia, comerciante de púrpura en Tiatira y persona devota. El señor le abrió el corazón para que prestara atención al discurso de Pablo. Se bautizó con toda su familia y nos rogaba: "Si me tienen por creyente en el Señor, vengan a hospedarse a mi casa y les insistía" (Hch 16,13-15).

Dicho espacio de oración en donde se encontraban Pablo y Silas no era precisamente una sinagoga, sino un lugar donde se reunían judíos y griegos admiradores del judaísmo. Allí, Pablo conversó con las mujeres presentes. Una de ellas era Lidia oriunda de Tiatira, ciudad ubicada en Asia Menor.

Como lo presenta (Hch 16,16-18), parte de la historia de la esclava profetisa es introducida por el grupo de mujeres congregadas para la celebración cúltica sabática, allí estaba Lidia.

El texto narra que cuando los misioneros fueron al lugar de adoración, una esclava llegó a su encuentro y, a partir de ese momento, los siguió:

Un día, cuando íbamos al lugar en donde se reunirían para orar, nos salió al encuentro una muchacha que tenía un espíritu de adivinación gracias al cual procuraba a sus dueños grandes ganancias. La muchacha comenzó a seguir a Pablo y a nosotros gritando: estos hombres son siervos de Dios Altísimo; ellos les anuncian el camino de la salvación (Hch 16,16-18).

Ni Hechos de los Apóstoles, ni ninguna otra fuente bibliográfica cuenta cuándo y dónde nació y murió esta muchacha, ni quiénes fueron sus padres. Solo dice que posee un espíritu de adivinación.

Para algunos estudiosos, la muchacha no tiene un espíritu pitón; adivinación, como la exégesis tradicional lo señala, ya que su pronunciamiento respecto a los misioneros es teológicamente correcto. Es decir, el enunciado "Dios altísimo" -Theós húpsistos-era utilizado por judíos y gentiles al momento de describir al Dios de Israel ${ }^{34}$.

34 Pablo Richard, El movimiento de Jesús antes de la iglesia: una interpretación liberadora de los Hechos de los Apóstoles (San José de Costa Rica: DEI, 1998), 114. 
Como lo muestra el libro de Hechos de los Apóstoles, durante varios días la esclava proclamó abiertamente la identidad de los misioneros, situación que llevó a Pablo a indignarse y desterrar de la esclava el espíritu de adivinación:

... Pablo se hartó y, enfrentándose con el espíritu, le dijo: en nombre de Jesucristo te mando que salgas de ella. El espíritu salió de ella en ese mismo instante (Hch 18).

Respecto a lo anterior, la acción de Pablo evidenció que la esclava no era entendida como sujeto de acción mántica, ya que el misionero no se dirige a ella como a una persona con potencialidades humanas extraordinarias, sino se dirige al espíritu de una serpiente pitón, ordenándole salir de la mujer en nombre de Jesucristo ${ }^{35}$. Pablo no actúa con carácter profético, sino que actúa debido a su cansancio y al desagrado que siente hacia la actitud de la muchacha ${ }^{36}$.

Lo que $($ Hch 16,18$)$ revela es una disputa entre el Mesías judío, Jesucristo, y Apolo. El encuentro entre Pablo y la mujer profetisa se transformó en una disputa de poderes divinos cuando Pablo percibió, en el poder de la esclava, cierta competencia. No se puede descartar que la esclava estuviera disponiendo el camino de los misioneros, anunciándolos. Sin embargo, debe considerarse que el anuncio público hecho por la esclava profetisa colocaba en peligro a los misioneros, ya que se levantaba sobre ellos sospecha de propaganda prosélita en aquella provincia romana ${ }^{37}$.

Tal parece que Pablo destruye la capacidad espiritual de esta mujer colocándola, desde una perspectiva histórica, en una situación inferior. La esclava profetisa perdió el don de anunciar oráculos, motivo por el cual sus propietarios pierden una fuente de ingreso y ella los pocos beneficios que tenía para subsistir. ciones sobre Hech.16, 16-18", op. cit.

36 Pablo Richard, El movimiento de Jesús antes de la iglesia: una interpretación liberadora de los Hechos de los Apóstoles, op. cit., 115.

37 Richter Ivoni, “Una esclava profetisa y..., op. cit., 125. 
La mayoría de estudiosos de la Biblia ven en la acción de Pablo una "liberación de espíritus como si la esclava se hallara mal espiritualmente". Al contrario, los exégetas que tienen en cuenta algunos aspectos histórico-legales de la época creen que la expulsión del espíritu pitón damnifica a la muchacha ${ }^{38}$. En este sentido, Pablo convirtió a esta mujer en un instrumento sin valor para sus propietarios. Cabe anotar que la acción religiosa de Pablo interviene en la concepción jurídico-legal romana (no causar daño a la propiedad ajena). La acción religiosa -expulsar el espíritu-realizada por Pablo, culmina en una denuncia político-legal por parte de los dueños de la esclava.

Se resalta que existe una posibilidad histórica e interpretativa de liberación de la esclava, distinta a la mostrada por la exégesis dominante. La liberación está relacionada con la proseuchés9 o lugar de encuentro. La proseuché no se utilizaba únicamente los sábados para las solemnidades cúltico-litúrgicas. También servía para los favores comunitarios entre semana ${ }^{40}$.

Ahora bien, no se puede negar que la estadía de los misioneros en Filipos estuvo marcada por la presencia de la esclava. El interés de la esclava por los misioneros podía estar motivado por la ilusión de su libertad. De ahí que la proseuché, y poder estar allí, ofrecía el espacio indicado y las posibilidades para pensar una nueva vida mediante el apoyo de la comunidad judeo-cristiana.

Si algo así sucedió, es posible encontrar a la esclava ahora liberta entre las personas que se congregaban en casa de Lidia ${ }^{41}$. En este sentido, la historia de Lidia y la historia de la esclava profetisa pueden pensarse como historias complementarias. Pero, si no se cuenta con esta posibilidad histórica, la situación real de la muchacha empeoró al perder sus dones espirituales ${ }^{42}$.

\footnotetext{
38 Ibíd., 128.

39 Predio Sinagogal.

40 Richter Ivoni, “Una esclava profetisa y ... op. cit., 132.

41 Richter Ivoni, "Reconstruir historias de mujeres: consideraciones acerca del trabajo y status de Lidia en Hechos 16," op. cit.

42 Richter Ivoni, "Una esclava profetisa y ... op. cit., 131.
} 
Ahora bien, al volver a la escena en donde Pablo y Silas acuden el sábado al lugar de oración, es posible encontrar a los misioneros hablando con Lidia vendedora de púrpura. El relato dice: "Que el Señor le abrió el corazón para que pusiera atención a lo que decía el misionero... y se bautizó ella con toda su casa".

Para la exégesis dominante Lidia era una viuda y rica, que poseía una casa en donde recibía misioneros y en donde poseía esclavos necesarios para su ejercicio. Esta perspectiva descarta los aportes a esta historia fruto de los estudios extra bíblicos ${ }^{43}$. Por ejemplo, a través de investigaciones de carácter histórico se ha podido constatar que Lidia era porfirópolis: vendedora y productora de púrpura. Esta mujer no solo vendía púrpura, también extraía la púrpura del mar y de los vegetales. Cabe resaltar que tanto las personas que extraían la púrpura de los calamares del mar, como las que extraían la púrpura de los vegetales, realizaban un largo y arduo proceso de producción ${ }^{44}$ que producía un olor fuerte y desagradable que persistía por mucho tiempo ${ }^{45}$.

Para la alta sociedad romana Lidia desarrollaba una profesión indigna, una profesión indecorosa. No obstante, el fruto de su trabajo solo era consumido por individuos de clase alta. Aquí conviene decir que las mercaderías de púrpura, así como los tejidos en general, no eran elaborados en gran cantidad. Se trataba de producción y venta en pequeña escala para clases exclusivas.

Por otra parte, estas investigaciones extra-bíblicas muestran que Lidia no estaba sola en Filipos. Se encontraba con otras mujeres y hombres en la proseuché. Lidia ciertamente realizaba su trabajo en

\footnotetext{
43 Richter Ivoni, "Reconstruir historias de mujeres:... op. cit.

44 Según Richter, «La materia prima era triturada, salada y generalmente cocida. En esta etapa del proceso de producción eran añadidas a esa mezcla las así llamadas medicamenta. O sea, otras substancias como por ejemplo la orina que servía para fijar el color y tornarlo así, más durable. Después de algunos días de "fermentación" -la tonalidad del color dependía del tiempo de "fermentación" y de la intensidad de la mezcla-, se ponía en ella la lana para teñirla. Después de algún tiempo, lo teñido era expuesto al sol, con el fin de que el color quedase más firme y más brilloso.» Cf. Ibíd. Cf. Ibíd.
} 
comunidad y en casa ${ }^{46}$. Esta mujer disfrutaba de un cargo directivo en su grupo, lo que advierte sobre el uso del genitivo "la casa de ella". Siendo así, no es imperioso especular sobre el asunto si Lidia tenía esclavas y esclavos o no, pues lo corriente sería que estuviera con personas co-liberadas ${ }^{47}$.

Lidia y "su casa" subsistían al margen de la sociedad romana por tres razones: por su trabajo (mal visto), por su origen (extranjero de Oriente) y por su pertenencia religiosa. Lidia sabe que judíos y cristianos no son bien vistos en la ciudad de Filipos, como lo muestra (Hch 16,20ss): "Y, presentándolos a los magistrados dijeron: Estos hombres están perturbando nuestra ciudad; son judíos..."

Lidia sabe que existen conflictos entre cristianos y romanos. Sabe que basta un solo motivo para la intervención de las autoridades romanas, como ocurrió con la detención de Pablo y Silas ${ }^{48}$.

El lucro que se percibe a partir del trabajo de la esclava constituye el eje del versículo 16 y la pérdida del mismo, a causa de la acción religiosa de Pablo, es el motivo por el cual los propietarios de la esclava reaccionan frente a las autoridades locales ${ }^{49}$. Para Lucas, es significativo resaltar ese aspecto pues es la ganancia, la no existencia de la misma, lo que da ligazón con (Hch 16,19-24):

Viendo sus dueños que se les había escapado la esperanza de negocio, tomaron a Pablo y Silas, los arrastraron hasta la plaza, ante las autoridades, y, presentándolos a los magistrados, dijeron: estos hombres están perturbando nuestra ciudad; son judíos y predican unas costumbres que nosotros, romanos, no podemos aceptar ni practicar. La gente se reunió contra ellos y los magistrados ordenaron que los desnudaran y los azotaran. Después de una buena paliza, los metieron en la cárcel y ordenaron

\footnotetext{
46 En este contexto no es preciso concebir oikos -casa como familia en sentido concreto-. Más bien, la palabra oikos debe vislumbrarse en relación con el trabajo y la profesión de Lidia. El término oikos también era habitualmente usado para definir un grupo de gente trabajadora, tanto en el sentido religioso como económico-comercial.

47 Cf. Ibíd.

48 Richter Ivoni, “Una esclava profetisa y... op. cit., 119.

49 Ídem.
} 
al carcelero que los vigilara con mucho cuidado. Recibió el encargo, los metió en el último calabozo y les sujetó los pies al cepo.

Desde el inicio Lidia y su casa insisten en procurar amparo a Pablo, aún cuando corren el riesgo de soportar represalias y persecución por parte del imperio. No obstante, ella y otras mujeres, incluyendo a la esclava sin nombre, continuaron la misión.

Después de lo sucedido en la prisión, Pablo y Silas van donde Lidia, a fin de dar ánimo a las hermanas y a los hermanos (v. 40). 32: "Al salir de la cárcel se dirigieron a casa de Lidia, saludaron, animaron a los hermanos y se marcharon".

\subsection{Un diálogo reconstructivo y revelador de la voluntad de Dios. \\ Dos mujeres: una de la antigüedad y otra de la actualidad ${ }^{50}$.}

Guadalupe se miró en el espejo y notó que su rostro se hallaba triste y envejecido; fue una primera confrontación con su realidad próxima, con su realidad inmediata. Su rostro expresaba el cansancio y desesperanza de quien vive una crisis, de quien padece un infortunio. Era cierto que su rostro y corazón se habían perdido en la incertidumbre y en la desconfianza hacia sí misma, hacia el otro y hacia Dios. Sin embargo, esa mañana, entre sus brazos cargaba con amor profundo a su pequeña hija de tres años y con algunas preguntas en los labios esperaba que el día comenzara:

¿Es posible para mí una vida justa? ¿Es posible para mí y para mis hijos una vida nueva?

A la anterior pregunta, la esclava sin nombre que se encontraba en la Colonia de Filipos cuando Pablo y Silas iniciaban su misión diría que sí.

50 En este fragmento no usaré notas a pie de página en virtud de su carácter narrativo. El diálogo que se presenta se fundamenta en la reconstrucción de algunos aspectos de la vida de Lidia y de la esclava profetisa, como se evidencia en el apartado anterior. Es de notar, que una parte de este diálogo fue presentado en el I Congreso de Teólogas Latinoamericanas y Alemanas en Argentina 2008. Cf. AA.VV., Sentires teológicos en perspectiva liberadora (Bogotá: PUJ, 2008). 
$\mathrm{Al}$ anochecer, Guadalupe dispuesta a orar, tomó la Biblia y en uno de sus pasajes se encontró con una mujer en la ciudad de Filipos, la esclava profetisa. Era una mujer bella, que venía de Oriente, con dones proféticos y que sabía hablar. Se asemejaba a uno de aquellos personajes itinerantes de cuentos de hadas que pronuncian, en voz alta, oráculos que provienen del Espíritu de Dios: ... Estos hombres son siervos de Dios Altísimo, que os anuncia un camino de salvación. Estos hombres, Pablo y Silas, son siervos del Dios de Israel.

Era interesante observar cómo una caracterización del Dios del pueblo judío era usada, por una esclava pagana, cuyas palabras eran proferidas públicamente y resaltaban por su claridad. Asimismo, era sorprendente ver cómo el contenido de su anuncio correspondía a lo que ellos eran, personas que sirven al pueblo judío, anunciando el camino de la salvación en una colonia romana.

-¿Quién es aquella mujer que habla en voz alta? "preguntó Guadalupe". ¿Quién es aquella mujer cuyo nombre no existe en las páginas de libros, que ejemplifica condiciones humanas tan grandes para la vida?

La esclava dijo: Soy yo, la mujer que salió al encuentro de los siervos del Señor de la tierra. Soy yo, la esclava profetisa, la esclava de los dones mánticos. Mi don era la profecía y mi anuncio verdadero.

Tal parece que el encuentro entre la esclava y los misioneros facilitó un seguimiento o, como se dice en griego, un katakoloutein semejante al encuentro que tuvo Jesús con las mujeres: "Las mujeres que lo habían acompañado desde Galilea fueron detrás para observar el sepulcro y cómo habían puesto el cadáver" (Lc 23,55). Ellas siguieron a Jesús desde Galilea. Por su parte, la esclava profetisa siguió a Pablo durante varios días, pero hablando en voz alta.

-Y tú, muchacha de cabello negro y largo, żquién eres?

Guadalupe, sin pensarlo mucho, exclamó: -mi nombre es Guadalupe. Soy madre cabeza de familia y, actualmente, vivo las consecuencias de la desintegración familiar y el abandono. Soy testigo, 
los últimos años, del incremento de mujeres al frente de su hogar como resultado de los fenómenos de migración, aumento de madres solteras, violencia intra-familiar, abandono por infidelidad y viudez causada por los conflictos armados. Igualmente, he experimentado las consecuencias del deterioro de las condiciones de trabajo en casa y fuera de ésta, representadas por la insostenibilidad económica, la baja calidad de vida y la escasez de tiempo para dedicarles a mis hijos.

Un silencio profundo invadió el espacio donde dialogaban. La esclava, que siempre habló en voz alta, esta vez ni susurró. Su actitud revelaba un esfuerzo por comprender los sentimientos de descontento, temor, soledad e injusticia social que expresaba Lupe cuando hablaba. La esclava supo que las obligaciones de Guadalupe eran abrumadoras y el cansancio que sentía era extremo. Posiblemente, no contaba con un apoyo en la realización de los quehaceres del hogar, el cuidado de los niños, los gastos de la casa, los momentos de soledad y en el advenimiento de la enfermedad.

Guadalupe continuó... y preguntó: -¿Cómo te llamas mujer? Hasta el momento no has pronunciado tu nombre.

-No tengo nombre. -Contesto la esclava... luego prosiguió: ... por lo menos para la elite predominante de mi tiempo. Para mis dueños solo era un instrumento de adivinación de allí mi anonimato. Pero tú, Guadalupe, puedes llamarme Jovita.

Guadalupe sintió una profunda confianza hacia aquella mujer que de manera natural le reveló su nombre. Dicha revelación la motivó a contar algunos detalles sobre su vida.

Con un gesto de simpatía Lupe dijo: -Jovita, quiero contarte mí historia. Nací el 28 de noviembre de 1967, en el seno de una familia pobre que dedicó toda su vida al reciclaje. Mi padre y mi madre recorrían las calles de esta ciudad, todas las noches, en búsqueda de cartón, papel y todo tipo de material reutilizable para vender en depósitos y talleres. Reciclar basura era, y aún es, un oficio desagra- 
decido no solo por las burlas y menosprecio social. También genera un progresivo deterioro en la salud.

De repente, Jovita interrumpió diciendo: Sabes Guadalupe, el solo comienzo de tu historia me hace recordar la vida de una gran mujer que acompañó mi historia de fe y liberación: Lidia de Tiatira. Lidia producía y comercializaba púrpura. Era una mujer adoradora del Dios verdadero. Su trabajo era tenido como indigno. Su trabajo y el de su familia eran despreciados por los romanos. Muchos creían que Lidia era una viuda rica y sola. Aquello que la historia no contó fue que Lidia no estaba sola en Filipos, se encontraba con otras mujeres y otros hombres con los cuales vivía en comunión. No se puede afirmar que era una viuda rica, mas sí se puede deducir por su procedencia y oficio que era una mujer fuerte, líder, sencilla y trabajadora que se ocupó de la proclamación del evangelio. A Lidia, más que a Pablo, le debo mí liberación. A Lidia y a su casa le debo gran admiración.

La historia de Lidia resultaba ser para Guadalupe una historia reveladora y desconocida sobre la cual más adelante continuarían hablando.

De repente, se sintió un silencio profundo... luego Guadalupe habló: -Antes de la muerte de mi madre nuestra familia estaba conformada por papá, mamá, siete hermanas y un hermano. Todos muy unidos. A pesar de la pobreza en la que vivíamos nunca nos falto nada, jamás tuvimos hambre y pudimos ir a la escuela.

-Mis padres hicieron todo para que no nos faltara nada. Cuando yo tuve 19 años, mamá falleció. Ese acontecimiento partió mí vida en dos. Recuerdo que el 23 de enero de 1994, "Emilia" mi madre murió. Papá quedó solo y a cargo de una familia muy grande que no pudo sacar adelante, ya que al morir mamá, papá comenzó a tener vacíos mentales, que casi lo llevan a la locura. Después de la muerte de mi madre, abandoné la casa paterna por dos razones. La primera, mi padre se había ido a vivir a donde mi tía por su enfermedad y yo 
me sentía profundamente abandonada. Segundo, no contaba con la ayuda de alguien que me defendiera a mí y a mis hermanas de los golpes que mi hermano nos propinaba durante sus ratos de ira y frustración. Estar en casa era una pesadilla, era como estar en el mismo infierno.

Guadalupe suspiro... Luego continúo: -Cuando salí de la casa de mis padres me dediqué a la venta ambulante. "Empecé a trabajar en los buses vendiendo dulces, galletas, lápices, agujas, promociones y esferos. Asimismo, continué reciclando como mis padres me lo habían enseñado".

Con tono distinto, Lupe señaló: -Sabes, Jovita, al igual que el oficio de Lidia reciclar basura, hoy día, es un trabajo socialmente despreciado. -Lupe continuó-: sabes, al igual que la comerciante de púrpura yo trabajo con las manos. Con la diferencia de que Lidia coloca sus diez dedos en la masa mucosa para producir la tintura, teñir la lana y manufacturar tejidos; su nariz está siempre oliendo el olor fuerte y repugnante de las mezclas. Yo por mi parte, pongo las manos en los desechos, que están en las bolsas de basura, en donde el olor de los excrementos, alimentos descompuestos y polvo se entrecruza produciendo en mi garganta una sensación de profundo asco. No obstante, frente a tal indignación, el alma vuelve a mi cuerpo, cuando resalta a mi vista una bolsa de papel, una botella de vidrió, un pedazo de alimento que es posible volver a utilizar. Aun cuando no parezca sensato para muchos, lo que para algunos es basura, para otros, como yo, es el sustento diario de nuestro hogar.

Jovita no podía explicar cómo la situación de una mujer del siglo XXI lograba recrear aspectos relevantes de la vida de una esclava y de la historia de una productora y comerciante de púrpura de la antigüedad. Lupe, intuyendo lo que la esclava pensaba, dijo: -Amiga mía, si así puedo llamarte, quiero que sepas que las historias de las mujeres de otras épocas se renuevan en las prácticas, actitudes y sueños de las mujeres de hoy. Yo realizo mi humanidad impactada por tu historia y así tu vida se revela ante mí como historia divina. 
Guadalupe continuó hablando sobre su vida, así: -En medio del ir y venir de la vida conocí el hombre con quien tuve mi primer hijo. Actualmente mi pequeño tiene 14 años y desea con todas sus fuerzas poder estudiar. Al cabo de un tiempo mi vida se convirtió en un abismo al lado de ese hombre. El me pegaba, llegaba y me estrellaba contra las paredes... así mismo, lo hizo con mi hijo. Raúl, como se llamaba, se había dedicado a explotarme económicamente. Si yo no llegaba a casa con el dinero que él pedía me maltrataba. Después de muchas humillaciones y golpizas lo demandé... fui a una estación de policía porque él golpeó muy feo a mi hijo y a mí. Hoy no he vuelto a saber nada de él.

-Cuatro años después conocí a Efraín, el padre de mis cuatro niñas. Los seis años después del nacimiento de mi primera hija fueron muy difíciles para nosotros. Vivíamos en la miseria total debajo de un puente al norte de la ciudad. iEfraín nos abandonó! En aquel lugar, debajo del puente, mi pequeña niña enfermó, lo cual me obligó a volver a la casa de mis padres. Había pasado mucho tiempo y allí, en medio del calor de hogar, fui bien acogida por mis hermanas.

-¿Cómo son tus hermanas Guadalupe? -Preguntó Jovita.

Guadalupe contestó: -Mujeres buenas, humildes y creyentes.

-¿Cómo es tu casa Guadalupe? -Nuevamente preguntó Jovita.

-Es una casa vieja, su fachada está deteriorada y al interior calurosa con algunos arreglos que resaltan a la vista. Cuando uno entra ve un largo corredor, de donde se desprende una serie de habitaciones a mano derecha. La primera habitación es una pesebrera, allí guardamos y alimentamos a tres caballos que halan la carreta que recolecta material para reciclar. Luego, hay varios cuartos en donde habitamos siete hermanas junto con nuestras familias. Yo ocupo el tercer cuarto. Allí estoy con mis cuatro hijos. Siguiendo hacia el fondo, se encuentra un patio, en donde mis hermanas y yo lavamos las canecas que un señor nos trae para lavar casi todos los días. 
-En nuestra casa cada una se encarga de sus cosas. Por ejemplo, yo lavo la ropa de mis hijos y la ropa mía. En cuanto al aseo de la casa lo repartimos. A una le toca el lunes, a la otra el martes, otra el miércoles... así, nuestra casita se mantiene limpia y agradable. El arriendo lo pagamos entre todas. Josefa que es la más juiciosa, recoge el dinero y se encarga de entregárselo al propietario.

-Sabes, Jovita, es un hermoso hogar, en donde se respira amor, alegría, compañerismo, hermandad y muchas ganas de vivir el día a día...

Mientras Guadalupe continuaba hablando, Jovita evocaba la casa de Lidia. Recordaba que más que una casa era un hogar, una familia. Allí se proclamaba la Buena Nueva. Se procuraba el perdón de los pecados. En casa de Lidia, se percibía la salvación y se hacía presente el Espíritu de Dios. Realmente, era una casa distinta a las casas de su época. Era un hogar-familia que rompía las barreras de la raza, religión, ética, clase y género-. Allí todos se sentaban a la mesa. Allí los roles no estaban previamente fijados, porque los ministerios o servicios se requerían dependiendo de las circunstancias y las necesidades de la comunidad. Allí, en esa comunidad, la esperanza de salvación israelita, que al comienzo estaba unida al templo de Jerusalén, se realizó en reciprocidad de la familia. La casa de Lidia fue casa misionera y para Jovita comunidad de sanación y liberación.

-¿̇En qué piensas bella esclava? -Dijo Guadalupe.

-Disculpa mujer... Mí distracción. -Dijo la esclava... prosiguió. Guadalupe -¿Cómo sostienes a tu familia?

Lupe contestó: -Retaqueando.

La esclava preguntó: -¿¿Qué es retaquear?

Guadalupe dijo: -Pedir monedas en la calle y vender dulces, esferos, lápices en los buses. Claro que también sostengo a mi familia lavando canecas, reciclando basura $y$, de vez en cuando, haciendo aseo en casa de una señora que alquila habitaciones. 
-Y tú bella Jovita... ¿̇cuál fue tu oficio? -Preguntó Guadalupe.

La esclava dijo: -Mi oficio era profetizar. Muchos pensaban que mis profecías y adivinaciones provenían del espíritu del pitón.

Guadalupe no comprendía.

La esclava afirmó: ...-Sí, la palabra "pitón" para la mayoría de personas de mi época era asociada con la serpiente que guarda el oráculo de Delfos y que profería palabras divinas. Asimismo, el nombre pitón era usado tanto para la caracterización del lugar, cuanto para la denominación de la cobra /dragón como lo expresa el mito ${ }^{51}$.

¿Acerca de qué mito hablas? -Preguntó Lupe.

Jovita continúo: -Según el mito, la cobra o dragón no tenía ningún poder profético, solo protegía el lugar del oráculo de Delfos. Cuentan que la serpiente había sido muerta por Apolo, el dios de la mántica, quien concedía a las pitonisas el don de la profecía y adivinación.

-Muchos pensaron que el espíritu que me inspiraba era el espíritu de la serpiente, como si mi don de la profecía emanara de un espíritu distinto al espíritu de Dios. Muchos pensaron que se trataba de un espíritu impuro como el que entró en el pobre hombre geraseno que Jesús curó.

-A pesar de llegar a ser una de las principales agentes del acontecimiento religioso de la época, tan solo fui portavoz de divinidades masculinas y, como médium, ni siquiera tenía influencia sobre la interpretación de mis profecías, que quedaban en manos de los sacerdotes.

-Este oficio religioso me convirtió en objeto religioso de grandes señores que disponían legalmente de mí y, siendo propiedad productiva, nunca me perteneció aquello que produje. Es más, la divinidad de la cual fui portavoz no consiguió liberarme de la esclavitud 
y la dependencia de mis amos, ya que faltaba fuerza para superar el límite entre los explotadores y la explotada. Mi trabajo religioso me mantuvo presa en las redes del usufructo y dependencia de una sociedad excluyente y explotadora.

Jovita... luego preguntó: -Lupe, ¿̇en la sociedad donde vives existe apoyo para las mujeres con jefatura femenina?

Lupe respondió: -Sí, pero es difícil sobrellevar situaciones en donde las mujeres nos encontramos en una posición desventajosa respecto al hombre y, sobre todo, en estratos sociales bajos como el mío. El gobierno ayuda a mujeres en mi condición mediante programas de gobierno. Por lo general, estos programas benefician a la mujer cabeza de familia en materia de acceso prioritario de tierras, cooperativas y empresas producto de la reforma agraria. No obstante, la cobertura que tiene este tipo de ayuda es limitada e incipiente para la demanda de necesidades que existe.

-Jovita. -Dijo Guadalupe-: ... Para que te lleves una idea muy general de la problemática, quiero que sepas que el sector más pobre de todos los sectores pobres en Colombia corresponde al de las mujeres con jefatura femenina. Para ponerte un ejemplo, el 53\% del total de la población desplazada está conformada por niñas y mujeres de las cuales el 32\% son jefas de hogar debido a viudez, ruptura de sus relaciones de pareja o las pérdidas de sus compañeros o de sus hijos en medio del conflicto. Esta situación, además de los problemas psico-sociales ocasionados por la salida forzada de sus lugares habituales de residencia, hace recaer casi exclusivamente en las mujeres la responsabilidad del sostenimiento afectivo y económico de la familia.

Jovita, preguntó: -¿̇Por qué sabes tanto Guadalupe?

Lupe contestó: -Un día comprendí, después de muchos errores y agravios, que la ignorancia es atrevida.

Guadalupe continuó: -Ser madre cabeza de familia no es una tragedia. No obstante, implica sobreponerse frente a situaciones 
muy difíciles que por lo general ameritan del concurso de dos. Dos, que deberían ser igualmente responsables en la construcción de un proyecto que un día comenzaron.

-Jovita, no te puedo negar que hay situaciones que nos desbordan. No obstante, también hay situaciones y personas que traen a nuestra vida, a través de sus testimonios, valor y esperanza. Por ejemplo, me siento mejor cuando recuerdo a Amanda, a Lourdes, a Judith Ortega y a la señora Blanca, ya que estas mujeres han regalado a mi vida aliento de vida. No en vano, Amanda sacó adelante a sus dos hijas, sin el apoyo de su esposo, trabajando como empleada doméstica en casa de un oficial. Su hija mayor pronto ingresará a la Universidad y su pequeña princesa de diez años estudia con alegría y entusiasmo en un colegio privado para niñas.

-Por su parte, la fortaleza de la señora Blanca frente al asesinato de su esposo en una vereda del Putumayo es signo de valentía. Recuerdo la entereza de doña Blanca cuando nos contó: “... Tiraron el cuerpo de mi esposo al río y la corriente lo arrastró cientos de kilómetros. Su cuerpo duró, más de un mes, perdido entre unos matorrales. El 19 de abril de 1970 me llamaron en horas de la tarde. Me dijeron que habían encontrado el cuerpo, querían traerlo a casa, pero su descomposición era terrible. Lo enterraron en un lugar totalmente ajeno a mí... me entregaron algunas cosas que sacaron de sus bolsillos: su cédula, las fotos de las niñas y su reloj... todo estaba enterito. Después de cinco años viajé al lugar en donde lo enterraron y llevé a su lugar de origen los restos de mi esposo. Con el tiempo, todo se fue normalizando y acepté los designios de la vida... Muchas veces y en medio de mi angustia sentí que Dios me llamaba al ejercicio de la oración, la perseverancia, la firmeza, la opción frente a los valores del mundo, la responsabilidad, la justicia y el amor gratuito... Seguramente Jesús veía en mí una oportunidad de fortalecimiento y me llamaba a recuperar la fuerza de su primer anuncio, y a renovar mi vocación de madre por la mediación de la voz de mis pequeñas hijas víctimas de la violencia de los grupos armados. Jesús me convocó sin 
reparos y con amor, a sabiendas de que mi desaliento y desilusión acrecentaba el distanciamiento que sentía hacia él.

Guadalupe calla y entre sollozos recuerda la imagen de la señora Blanca... Un silencio profundo reina en la habitación. Lupe se queda dormida y las páginas del libro se cierran. A la luz de su regazo duerme su pequeña hija, confiada al amparo de su madre, como quien recibe a Jesús con verdadera receptividad, como el verdadero don.

\subsection{Una hermenéutica bíblica como escenario de lucha por la liberación}

Realizar un examen de los textos bíblicos que abordan aspectos de la vida de Lidia y de la historia de la esclava profetisa presente en Hechos, implicó realizar un análisis del contexto cultural de la época en que Hechos de los Apóstoles fue escrito y su función. Asimismo, implicó aplicar, como a continuación se muestra, la interpretación bíblica crítica feminista de la liberación a partir de la danza de la sabiduría $^{52}$ en sus siete pasos, así:

\section{Hermenéutica de la experiencia ${ }^{53}$}

La experiencia es enseñanza que se adquiere con la práctica. Es acontecimiento que se vive y del que se aprende algo. Es sinónimo inclusive de costumbre, uso y hábito. También, es un saber público y privado que facilita comprender que libros como la Biblia fueron escritos dentro de formas culturales hegemónicas y dominantes. De hecho, es conocido que tanto en el mundo greco-romano como en el mundo bíblico, la mujer era excluida y silenciada. En este contexto no era aceptado que un escritor como Lucas destacara la actuación lúcida y valerosa de la mujer. Quizás, si no fuera por ese prejuicio... ide cuántos prodigios, respecto a las mujeres, nos hablaría Hechos de los Apóstoles! Quizás, si no fuera por tal preocupación icuántas ver-

52 Propuestos por Shüssler.

53 Considera la experiencia de la mujer como categoría fundamental. El papel de la mujer no había sido tenido en cuenta en el quehacer teológico y bíblico. 
dades respeto a Lidia se hubieran dicho y cuántas palabras de aliento y admiración se hubieran expresado a la esclava profetisa de Filipos!

Si la experiencia es enseñanza, es posible preguntarse entonces: ¿̇por qué Pablo, siendo siervo fiel del Señor, no comprendió con atenta calma las palabras que decía aquella esclava? Más aún, si la experiencia es sabiduría iporqué no la llamó por su nombre como lo hizo con otras mujeres, a sabiendas que el anuncio del Reino de Dios es una invitación no solo para creyentes sino también para paganos? Por ejemplo, Lidia aun cuando no habla en voz alta, acoge con fuerza y coraje hombres y mujeres de diferente raza, género, clase y etnia construyendo comunidad de iguales. Por su parte, la muchacha profetisa aun cuando es instrumento de una religión que la subyuga, habla en voz alta como lo hace Juan Bautista abriendo las puertas del camino de Jesús.

Experiencias de mujeres hay muchas y no deben comprenderse como una experiencia universal. Se trata de experiencias múltiples y complejas que solo pueden decir algo si se las mira como construcción social.

\section{Hermenéutica de la dominación y la ubicación social ${ }^{54}$}

El contexto en el cual nacemos nos precede y, queriendo o no, hacemos parte de éste. Algunas veces se nos presenta con simpatía, pero la mayoría de las veces como un "otro violento". Por lo general, advertimos la violencia y la exclusión contenida en la sociedad en relación a lo "diferente" -el esclavo, el enfermo, el pobre, el oprimido, el negro o la mujer-. El "otro distinto", que no cumple con los parámetros de un contexto específico desafía la manera como cada grupo, pueblo o nación percibe su identidad, costumbres y valores. Es la irrupción del "otro diferente", dentro de un esquema de conducta hegemónico y kyriarcal, lo que imprime la capacidad de hacernos

54 Realiza un análisis sistemático respecto a las estructuras sociales, culturales, políticas y religiosas de dominación dentro de contextos específicos. No solo examina las situaciones de dominación actuales, sino también las que se encuentran en la Sagrada Escritura. 
pensar libres y reflexivos frente a las estructuras sociales, económicas, políticas y religiosas impuestas.

Leer la Sagrada Escritura desde la perspectiva del diferente, implica aproximarse a una realidad sociohistórica específica. Por ejemplo, la esclava que presenta Lucas en Hechos de los Apóstoles $(16,16-18)$ es relegada a un tercer plano. Ella es: "mujer", "esclava", y ha nacido en "Oriente". Asimismo, expande su "religión" -mal vista por judíos y cristianos- en aquel lugar a donde ha llegado deportada. Y, como si fuera poco, en calidad de esclava es "instrumento de lucro" para sus señores -amos- que disponen legalmente de ella y con la autoridad que les da un imperio.

\section{Hermenéutica de la sospecha ${ }^{55}$}

Todo discurso sobre Jesús, que dé lugar a una actitud sectaria, al nosotros/ellos, tiene que resultar sospechoso. Tan dudoso como encontrar una aguja en las profundidades del mar... Y, si Pablo no busca sanar a la esclava profetisa, tan distinta a él, con la intención que Jesús sanó a los enfermos y liberó a los endemoniados, entonces, ¿qué busca? La tradición muestra, y la experiencia dice, que el objetivo del misionero era la expansión del evangelio. Pero, ¿̇el evangelio no es acaso el anuncio de la salvación, sanación y buena noticia a todos los pueblos de la tierra incluyendo incluso a los paganos e incrédulos? No obstante, parece que Pablo quiere fundar comunidades, no lograr conversiones individuales, pues el modelo de misión de Pablo no parte de la preocupación por la conversión de las personas, sino porque el evangelio llegue hasta el último rincón del mundo, pues se espera que si el evangelio llega a todas las naciones llega con estas la salvación de Israel.

55 La hermenéutica de la sospecha cuestiona y desmitifica las estructuras de dominación presentes en la Sagrada Escritura. Le interesa cuestionar las formas distorsionadas en las que la presencia y las prácticas actuales de las mujeres son construidas a través del lenguaje Kyriocentrico y de los medios de comunicación. 
Frente a estos textos, vale la pena preguntarse: ies el autor de Hechos un hombre sensibilizado por las motivaciones de la esclava profetisa y por las motivaciones de la productora y vendedera de púrpura que se encontraban en la colonia de Filipos? Más aún, es importante cuestionar ien Lucas se encuentra un vestigio de misericordia y aprecio hacia estas mujeres? Posiblemente sí, o entonces el autor de Hechos de los Apóstoles no hablaría a través de sus relatos acerca de mujeres que reciben misericordia, y sobre otras que ofrecen hospitalidad. Parece que la mentalidad de este autor está tejida de delicadeza y sensibilidad. ¿̇Acaso nos encontramos con un narrador ideal, capaz de entrar en perfecta sintonía con los sentimientos de las mujeres?... Pero, si fuera así, entonces ipor qué la esclava profetisa aparece relegada a un tercer plano en su obra? o, más bien ¿̇se tratará de un asunto de la exégesis dominante?

\section{Hermenéutica de la evaluación crítica y la proclamación ${ }^{56}$}

Los textos que forman la Sagrada Escritura proclaman la palabra de Dios. No obstante, la interpretación que se realiza en torno de estos puede proclamar con distorsión la revelación verdadera.

La acción religiosa de Pablo -el ejercicio de liberación de espíritus-, en relación al comportamiento de la esclava de los dones mánticos, contradice el mensaje esperanzador y liberador de Dios, por lo menos desde una exégesis no tradicional. Lo que realmente se evalúa, frente al comportamiento de Pablo, es su actitud defensiva frente a la presencia y palabras correctas dichas por la esclava profetisa: "estos hombres son siervos del Dios Altísimo; ellos les anuncian el camino de la salvación" (Hch 16,17).

56 Implica evaluar los datos de la hermenéutica de la sospecha. Este tipo de interpretación evalúa la retórica de los textos y las tradiciones, asimismo la de los discursos contemporáneos, con una escala de valores feminista-liberacionista. La hermenéutica de la evaluación tiene un doble objetivo: ayuda a tomar conciencia de las formas culturales y religiosas de interiorización y legitimación del kyriarcado, y analizar los valores y visiones que se encuentran en los textos bíblicos a modo de alternativas contraculturales. 
En lo que a mí respecta, las palabras proferidas por la muchacha no denotan una rivalidad entre dioses o una negación de la misión emprendida por Pablo. Por el contrario, auguran la proclamación del Reino de Dios y la venida de la salvación a partir de un camino que ella aún no conoce.

\section{Hermenéutica de la imaginación creativa ${ }^{57}$}

Allí, en su casa, como una excelente receptora y guardadora de noticias, Lidia la recibió. La manera como Lidia le enseñaba la "Palabra" consolidó en la esclava profetisa la esperanza de la Iglesia. Allí, una vez más, el anhelo de Jesús marca la diferencia entre un mundo dividido entre nosotras y ellos, y un mundo de un nosotras en contraposición a nadie. Lidia y su casa viven sin antagonismos, sin exclusivismo y sin discriminación. Recorren casas y veredas llevando las mismas palabras de María, y animando y consolando el rostro humilde y triste de las y los desposeídos de la tierra. La fuerza de "la casa de Lidia" es arrolladora, pero su contexto la oprime. Y, aun cuando su sociedad está en crisis, la fuerza del espíritu de Dios la sostiene como sostiene una madre a su hijo entre sus brazos.

¿Cómo sería el cuidado y la atención que brindaría la esclava de los dones mánticos a Lidia de Tiatira los últimos años, cuando las fuerzas declinan notoriamente y el espíritu toca las anhelos más altos? Seguramente, la actitud de la muchacha reflejaba un sentimiento sublime de gratitud hacia una mujer limpia, desinteresada y humilde. Con seguridad, las palabras que la esclava profería predecían la unión definitiva de Lidia con su salvador. De más, sus palabras retumbaban al interior de "la casa de Lidia" como las palabras que retumban en el corazón de hombres y mujeres cuando alguien habla en las plazas públicas desafiando la insensatez de las personas y de la vida.

57 Intenta generar visiones utópicas sobre un mundo distinto caracterizado por la justicia y el bienestar a partir de la imaginación de libertad. 


\section{Hermenéutica de la remembranza y la reconstrucción ${ }^{58}$}

La muchacha buscaba el sentido oculto y profundo de aquellos hechos y palabras: "En nombre de Jesucristo te ordeno que salgas de ella...", y los confronta con las nuevas situaciones en las que su vida se ve envuelta. De esa forma, sus recuerdos se conservan en su memoria como estelas que nunca se apagan. Lo único que aquella mujer no recuerda fue el motivo por el cual Pablo la exorciza de un espíritu impuro, cuando su espíritu era reflejo del espíritu de Dios. También recuerda cómo no se quebró emocionalmente bajo aquel peso infinito que avergüenza, y cómo no escapó espantada después de tanta denigración y falta de astucia.

La muchacha, en el instante cuando Pablo la despojaba de su espíritu profético, recordaba la audacia y la fortaleza con la que se desenvolvía la Iglesia de Lidia en aquellos primeros días. Sin lugar a dudas, recuerda cómo saltó solitaria de una fe ingenua a una madurez en la fe. Y, llena de paz, humildad y dulzura, confía y se entrega al Señor en medio de la ira de quien parece su adversario.

Ella, por su parte, es capaz de olvidar sus recuerdos que la atan a lugares, circunstancias y personas dejando de sentirse indefensa y oprimida por ellas. Ahora es capaz de comprender que lo que se justifica ante nosotros mismos, forma parte de la misma relación destructiva con los demás.

\section{Hermenéutica de la acción transformadora para el cambio ${ }^{59}$}

Hace falta un cambio de visión, un cambio de mentalidad, un cambio de actitud en medio de la pretendida superioridad de los sistemas hegemónicos antiguos y contemporáneos. el conocimiento e imaginación histórica de las mujeres y cuestiona el abismo que el positivismo histórico ha abierto entre el lector contemporáneo y los textos bíblicos.

59 Esta hermenéutica constituye el objetivo de la danza hermenéutica, ya que tal proceso interpretativo busca alterar las relaciones de dominación legitimadas e inspiradoras por las religiones bíblicas kyriarcales. Es así como explora vías y posibilidades de transformación de las relaciones de dominación inscritas en los textos, en las tradiciones y en la vida cotidiana. Rinde cuenta a las mujeres que luchan en la base de la pirámide kyriarcal de discriminación y dominación. 
Porqué no soñar y, más que soñar, luchar por una sociedad más justa, inclusiva y desinteresada.

Porqué no luchar con decisión por una sociedad en donde niños, viejos, pobres, mujeres y jóvenes levanten las banderas de la libertad y de la no exclusión y explotación.

Porqué no soñar más que en un mundo viejo en un mundo nuevo en donde los "desconocidos sociales" ya no tengan que resistirse a las bandas armadas de los imperios y a las imposiciones del libre mercado.

Porqué no luchar por un mundo en donde se preserven las bases mismas de la existencia humana, y se valore abiertamente la vida.

Porqué no soñar en una sociedad autónoma e igualitaria que no se oriente a la generación de riqueza para sostener las elites y esquemas dominantes.

Porqué no luchar por una sociedad que no produzca pobreza y degradación, y que no rechace radicalmente la presencia de Dios.

Y, por último, porqué no pensar críticamente y de manera creativa un camino que transforme la vida.

\section{Conclusiones}

En asuntos que tocan nuestra comprensión y conducta, como mujeres o como hombres, a menudo topamos con opiniones, imposiciones y restricciones de tipo patriarcal y machista que tienen su fundamento en la fe cristiana y, por ende, en la Biblia. En este sentido, la teología, hermenéutica y exégesis feminista ${ }^{60}$ hacen una crítica

60 Cf. María Teresa Porcile, La mujer, espacio de salvación: misión de la mujer en la Iglesia, una perspectiva antropológica (Madrid: Anzos, S.L. Fuenlabrada, 1995); Rosemary Radford, "Hermenéutica feminista un método de correlación", en Letty Russell, Interpretación de la Biblia (Bilbao: Desclée de Brouwer, 1995); José María Mardones (Dir.), 10 Palabras claves sobre movimientos sociales (Estella: Verbo Divino, 1996); Victoria Howell, En clave de Mujer: relectura del evangelio de Lucas (Bilbao: Desclée de Brouwer, 1998); Olga Consuelo Vélez, Mujer y teología, Una aproximación (Bogotá: Centro Editorial Javeriano, 2001) y "Teología de la mujer, feminismo y género", Theologica Xaveriana 140 (2001): 545-563; Socorro Vivas, "Género y teología", Theologica Xaveriana 140 (2001): 525-544. 
respecto a todo lo que excluye, oprime y subordina a las mujeres, ya que es contrario a la revelación de Dios que se transparenta en la vida y testimonio de Jesús.

Cuando se lee el texto sagrado desde una perspectiva feminista y de género, se percata que hay textos dentro de la Biblia que deshonran el ser de la mujer y la colocan en una posición inferior respecto al varón. El proceso hermenéutico crítico de talante retórico emancipador, propio de la teología feminista, desafía a los estudios bíblicos y a sus lectores a convertirse en lectores capaces de discernir el carácter modernista de los estudios bíblicos y sus propias ubicaciones y funciones sociopolíticas, dentro de estructuras globales de dominación.

Para interpretar y evaluar los testimonios que se hallan en el Nuevo Testamento se debe tener como clave de interpretación la persona y el testimonio de vida de Jesús. Jesús tuvo un trato especial con las mujeres, distinto al de la sociedad judía patriarcal. Asimismo, la primitiva comunidad cristiana acogió a la mujer como persona digna, discípula y seguidora. Por demás, mantuvo viva la memoria de Jesús, su comportamiento equitativo con todas las personas.

Muchas mujeres, pudiendo ceñirse a los principios cristianos de igualdad, permiten al interior de las prácticas socioculturales ser discriminadas. Colombia es un país regido por un gobierno patriarcal, ya sea desde lo estatal, empresarial, eclesial y familiar. No obstante, no existe un sustento que valide la pretendida superioridad del hombre sobre la mujer que la filosofía y las teologías antiguas sostuvieron.

Luchar por un futuro diferente y más justo para todos es una necesidad y una prioridad, frente a realidades deplorables como la situación de inequidad que viven cientos de mujeres en Colombia. Se subraya que los hogares más pobres del país tienen como cabeza de familia una mujer, cuya jefatura femenina se originó como consecuencia de viudez, madre solterismo, desplazamiento forzado y fenómenos de migración, violencia intrafamiliar y abandono. 
La recuperación de la vida de Lidia de Tiatira, la esclava profetisa de Filipos y la mujer jefe de hogar en Colombia, en nuestra memoria, destaca la fecundidad de las relaciones interdisciplinares en el trabajo exegético por parte de las mujeres. Los estudios bíblicos feministas resultan ser un espacio de coraje, esperanza y visión de futuro en medio de las luchas por la justicia de hombres y mujeres.

La investigación histórica, sociológica y antropológica cultural de la antigüedad ha permitido reconstruir escenarios y costumbres, y recabar información sobre aquellos ambientes en los cuales aparecen las mujeres del siglo primero, y de las que nos hablan el libro de Hechos de los Apóstoles.

El momento demanda, por parte del teólogo, reafirmar el sentido profético de su misión. Por consiguiente, debe estar al tanto de la situación que vive el pueblo, especialmente de las repercusiones en el pueblo excluido. Igualmente, le pide analizar el pasado y el presente para elaborar visiones creativas e imágenes inusitadas de una nueva humanidad; un lugar donde acontece la salvación y la revelación. Lo anterior supone reconocer que Dios se revela a los hombres a través de sus obras, que acontecieron y siguen aconteciendo en la historia y no solo a través de su palabra.

\section{Bibliografía}

Aguirre, Rafael. "La primera evangelización". En Kerigma, discipulado y misión: perspectivas actuales. En la Colección Quinta Conferencia Biblia. Bogotá: CELAM, 2006.

AA.VV. Sentires teológicos en perspectiva liberadora. Bogotá: PUJ, 2008.

Baena, G. Apuntes personales en el marco de la Jornada de Reflexión sobre Investigación. Facultad de Teología de la Pontificia Universidad Javeriana de Bogotá, el 9 de enero de 2008. 
Campillo, Fabiola. "El Trabajo Doméstico no remunerado en la Economía". En Macroeconomía, Género y Estado. Bogotá: TM Editores, 1998.

Concilium. Las escrituras sagradas de las mujeres 276 (junio 1998).

Concordancia de las Sagradas Escrituras. Revisión de 1960 de la versión Reina- Valera. Compilada por Denyer, C.B. Nashville: Editorial Caribe, 1978.

De Roux, Rodolfo. Apuntes personales en el marco de la Jornada de Reflexión sobre Investigación. Facultad de Teología de la Pontifica Universidad Javeriana de Bogotá, el 9 de enero de 2008.

Díaz, Dora Isabel. Situación de la mujer rural colombiana. Perspectiva de género. Cuadernos Tierra y Justicia 9. Bogotá: ILSA, 2002.

Forcano, Benjamín y Boff, Leonardo. Liberación de Jesucristo por el camino de la opresión. Madrid: Nueva Utopía, 1997.

Godard, F. y Cabanes, G. Uso de las historias de vida en ciencis sociales. Bogotá: Universidad Externado, 1996.

Howell, Victoria. En clave de Mujer: relectura del evangelio de Lucas. Bilbao: Desclée de Brouwer, 1998.

Instituto Nacional de Medicina Legal y Ciencias Forenses y Fondo de Prevención Vial. Forensis, datos para la vida. Bogotá: 2002.

Londoño Vélez, Argelia. Derecho a los derechos. Atención integral a sobrevivientes de delitos sexuales. Bogotá: Consejería Presidencial para la Política Social y Fondo de Población de las Naciones Unidas, 2001.

Mardones, José María (director). 10 palabras claves sobre movimientos sociales. Estella: Verbo Divino, 1996.

Marguerat, Daniel y Bourquin, Yvan. Cómo leer los relatos bíblicos. Santander: Editorial Sal Terrae, 2000. 
Navarro, Mercedes. "Los apóstoles y sus hechos: mujeres en los hechos de los apóstoles". En En clave de mujer: relectura de Lucas. Bilbao: Desclee de Brouwer, 1998.

Porcile, María Teresa. La mujer, espacio de salvación: misión de la mujer en la Iglesia, una perspectiva antropológica. Madrid: Anzos, S.L. Fuenlabrada, 1995.

Profamilia. Encuesta nacional de demografía y salud ENDS. Bogotá: 2000 .

Richard, Pablo. El movimiento de Jesús antes de la Iglesia: una interpretación de los Hechos de los Apóstoles. San José: DEI, 1998.

. "Los diversos orígenes del cristianismo: Una visión en conjunto (30-70 d.c)". Revista de Interpretación Bíblica Latinoamericana 22 (1996): 43-57.

Richter, Ivoni. "Reconstruir historias de mujeres: consideraciones acerca del trabajo y status de Lidia en Hechos16." Revista de Interpretación Bíblica Latinoamericana 4 (1989): 47-59.

. "Una esclava profetisa y misioneros cristianos $\dot{i}$ Experiencias de liberación? Consideraciones sobre Hch 16,16-18." Revista de Interpretación Bíblica Latinoamericana 12 (1992): 117-133.

. "Recordar, transmitir, actuar. Mujeres en los comienzos del cristianismo". Revista de Interpretación Bíblica Latinoamericana 22 (1996): 43-57.

. "Sexualidad en tiempos escatológicos: una aproximación a la problemática del matrimonio y del celibato en los dos primeros siglos cristianos". Revista de Interpretación Bíblica Latinoamericana 29 (1998): 106-119.

Schökel, Luis Alonso. La Biblia de nuestro pueblo. Bilbao: Ediciones Mensajero, S.A.U., 2006. 
Schüssler, Elisabeth. En memoria de ella. Una reconstrucción teológico-feminista de los orígenes del cristianismo. Bilbao: Desclée, 1989.

. Los caminos de la sabiduría. Santander: Sal Terrae, 2004. . Pero ella dijo. Madrid: Trotta, 1996.

Torres, Alfonso. Aprender a investigar en comunidad I. Bogotá: Unisur, 1996.

. Enfoques cualitativos y participativos en investigación social: aprender en comunidad II. Bogotá: Unad, 1997.

. Estrategias y técnicas de investigación cualitativa. Bogotá: Unisur, 1996.

Radford, Rosemary. "Hermenéutica feminista un método de correlación". En Russell, Letty. Interpretación de la Biblia. Bilbao: Desclée de Brouwer, 1995.

República de Colombia. Consejería Presidencial para la Equidad de la Mujer. Informe de Gestión. Bogotá: 1999.

Universidad Nacional de Colombia. CID. UNICEF. “ $i E q u i d a d ~ d e$ género? ¿Equidad social? Una mirada desde la educación y el trabajo," Observatorio de Coyuntura Socioeconómica 14 (diciembre 2002).

Vizcaíno, Ximena. La mujer en la Iglesia: del silencio a la palabra, del olvido a la memoria, de la pasividad a la militancia. Colección Apuntes de Teología. Bogotá: PUJ, 2005.

Vélez, Consuelo. Mujer y teología, una aproximación. Bogotá: Centro Editorial Javeriano, 2001.

. "Teología de la mujer, feminismo y género". Theologica Xaveriana 140 (2001): 545-563.

Vivas, Socorro. "Género y teología". Theologica Xaveriana 140 (2001): 525-544. 